\title{
Divergrass - A Cross Border Project to Promote Sustainable MANAGEMENT OF GRASSLANDS
}

\author{
Jan Titěra $^{1}$; Henning Haase ${ }^{2}$; Teowdroes Kassahun Teka ${ }^{3}$ Chukwudi Nwaogu ${ }^{4}$; \\ Klára Pavlü ; Matthias Kändler ${ }^{6}$; Lenka Pavlů ${ }^{7}$; Jan Gaisler ${ }^{8}$; František Paška $^{9}$; \\ Heike Heidenreich $^{10}$; $_{\text {Gerlinde Liepelt }}{ }^{11}$; Irena Jonášová ${ }^{12}$; Vilem Pavlü ${ }^{13}$ \\ 1, 3, 4, 5,7 Česká zemědělská univerzita v Praze, Faculty of Environmental Sciences, \\ Department of Ecology, Laboratory of Agroecosystems Study \\ Rolnická 85/6, 46011 Liberec, Czech Republic \\ 2, 6, 10, 11 Technische Universität Dresden, International Institute Zittau, \\ Chair of Biotechnology, \\ Markt 23, 02763 Zittau, Germany \\ 1, 8, 9, 12,13 Výzkumný ústav rostlinné výroby, v.v.i., \\ Department of Weeds and Vegetation of Agroecosystems, \\ Grassland Research Station Liberec, \\ Rolnická 85/6, 46011 Liberec, Czech Republic \\ e-mail: ${ }^{1}$ titeraj@fzp.czu.cz; ${ }^{2}$ henning.haase@tu-dresden.de; ${ }^{3}$ teka@fzp.czu.cz; \\ ${ }^{4}$ cnwaogu@gmail.cz; ${ }^{5}$ kpavlu@fzp.czu.cz; ${ }^{6}$ matthias.kaendler@tu-dresden.de; \\ 7pavlul@fzp.czu.cz; ${ }^{8}$ gaisler@ vurv.cz; ${ }^{9}$ paska@vurv.cz; ${ }^{10}$ heike.heidenreich@tu-dresden.de; \\ ${ }^{11}$ gerlinde.liepelt@tu-dresden.de; ${ }^{12}$ jonasova@vurv.cz; ${ }^{13}$ pavlu@vurv.cz
}

\begin{abstract}
Most temperate European meadows and pastures belong to semi-natural and temporarily sown intensive grasslands. Semi-natural, mostly rich grasslands species have been maintained by agriculture activities for centuries. However, intensive grasslands are a more modern but widespread phenomenon nowadays. Livestock grazing is the key management for pastures and regular cutting for meadows. A combination of grazing and cutting is typical for grazed meadows. The absence of grassland defoliation, extensification and too intensive management can lead to a decline in plant species diversity resulting in disappearance of endangered plant species. Decreasing of grassland diversity in natural habitats is one of key problems in present nature protection on both sides of Czech (CZ) / German (D) border. In the transboundary region comprising the Jizerské hory Mts $(\mathrm{CZ})$, the Lužické hory Mts $(\mathrm{CZ})$ and the Zittauer Gebirge Mts and foreland (D), twelve manipulative management experiments were established in DiverGrass project on different types of grasslands in order to find optimal measures for stopping declining or increasing of plant species diversity in grasslands habitats.
\end{abstract}

\section{Keywords}

Grassland; Management; Grazing; Cutting; Biodiversity; Nature protection.

\section{Introduction}

A high decline in biodiversity has been reported in different habitats by many international and national studies, e.g. $[1,2,3]$. The recent monitoring report on the Natura 2000 habitats in Saxony showed a clear negative trend for grassland biotopes [4]. A large decrease in rare and protected plant species on valuable grassland habitats and a broad loss of conservation quality has been observed by the nature conservation authorities of the Liberec Region and Görlitz District. 
General species depletion was found in grassland habitats, although these areas were cultivated as prescribed and with conservation funding. To identify possible reasons for the decline and to reverse the trend by developing and promoting measures for a sustainable management of the valuable habitants, the project 'DiverGrass' was established.

\section{$1 \quad$ Theoretical Background}

\subsection{Importance of Temperate Central European Grassland}

In temperate regions of Europe, grasslands are major components of the landscapes because for centuries they have been playing a vital role in the economic activity including animal production. Grassland is one of the biomes that have a well-developed equilibrium mechanism and stability even in absence of additional input of energy [5, 6]. Although there are large variations in soil condition, climate and history, grasslands across Europe can be distinguished as permanent and temporary grasslands, with the latter consisting of some proportion of forage legumes. Most of the grasslands found in Central European conditions do not represent climax communities as they were largely created after large-scale deforestation and maintained by agricultural activities. In general, grazing and mowing have been the most widely used management strategy for centuries, in some areas possibly as far back as in Neolithic or Bronze ages. These grasslands possess not only natural values, but have also huge cultural historical value, as they have been under the influence of humans for several generations $[7,8]$.

A review by Hejcman et al. [9] divides grasslands in Central Europe into three broad categories based on their origin: i) Natural grasslands are differentiated by the climatic conditions such as limitation of soil moisture, which is common for a steppe region on the eastern border of Central Europe and low temperature with shorter growing season for higher mountains above the upper tree limit; ii) Semi-natural grasslands were mostly linked to human interaction starting from the beginning of agricultural practices during the MesolithicNeolithic transition; iii) Intensive grasslands are the result of intensive agriculture, which includes sowing of highly productive forage grasses and legumes. Semi-natural and intensive grasslands can be further divided based on the management system they belong to, including pastures, meadows, and grazed meadows. They have a wide range of species richness of vascular plants ranging from 1 to 67 species and herbage production from 1 to 10-ton dry matter per hectare. Livestock grazing is the key management for pastures, regular cutting for meadows and cutting in summer and grazing in spring/autumn for grazed meadows.

The countries in Central Europe are comparatively high yield zones, with annual production between 4 to $6 \mathrm{t} \mathrm{ha}^{-1}$. Overall, the variation in productivity between years could be significantly different and this could be related to variability in climate [10].

The existence of temperate grasslands could be attributed to moderate disturbances such as grazing, mowing or fire incidences. Most of them are sub-climax communities; hence they require periodic defoliation to avoid succession that could lead to being converted into shrubs and woodlands [11]. During the last millennia, temperate European grasslands have been largely managed by grazing of domestic animals or by hay making activities. This is one of the main reasons why this ecosystem is mostly described as semi-natural. It just implies the importance of grazing by wild or domestic animals. In general, they are dependent on a form of disturbance that inhibits dominance of woody plant species [12].

The decline in grassland diversity and overall biological diversity has been ongoing for the last hundred years [3,6]. Among several reasons, changes of agricultural management such as intensive milk husbandry in cowsheds are top on the list leaving only a few portions of 
grassland to be used extensively and the vast amount of former semi-natural grassland to be abandoned [6]. Recently, the situation is much more serious in less accessible areas such as mountainous areas that have low productivity, where semi-natural grassland is common. However, the lowland meadows were nearly completely destroyed as they were ploughed in the last fifty years $[3,6]$. 'Extensification' in terms of avoiding or minimizing the intensive application of fertilizers as well as a change in the frequency and timing of defoliation can be beneficial. But in reality, it can be challenging as it can bring various risks due to the temporary or total abandonment of the grasslands. The absence of grassland defoliation leads to a decline in plant species diversity [13], and abundance of tall species as more litter on the ground promotes the nutrient availability and restricting seedling emergence [14]. As more intensification of livestock production with larger and more specialized farm units continue to develop, the more the role of grasslands in livestock production diminishes [15]. This trend will probably continue as an intensification of cattle production with highly digestible forages from arable lands and concentrates is applied [16, 17].

\subsection{Characteristics of the Project Area with Focus on Grasslands}

\subsubsection{The Zittauer Gebirge Mts and Foreland}

The German part of the project area is confined by the extent of the former administrative district of Zittau with approximate landmass of $252 \mathrm{~km}^{2}$. It contains the municipalities of Oybin, Jonsdorf, Großschönau, Zittau, Olbersdorf, Bertsdorf-Hörnitz, Mittelherwigsdorf, Hainewalde, Leutersdorf, Oderwitz and Seifhennersdorf. Physiogeographically it is divided into the two natural regions "Zittauer Gebirge" (Zittauer Gebirge Mountains) and the southern part of the "Östliche Oberlausitz" (Eastern Upper Lusatia) [18]. Geographically, it is bordered in the west and south by the Czech Republic and in the east by Poland. Nearly two-thirds of the land use in the project area is agriculture (Fig. 1) [19]. The overall proportion of grassland is about $21 \%$. Only a tiny fraction of the grassland (1.4\%) is protected grassland in the sense of §21 Saxony Law on Nature protection (SächsNatSchG) [20] and could therefore be addressed as semi-natural grassland according to [9], and this is only $0.3 \%$ of the total area.

The Zittauer Gebirge Mts as German part of the Lusatian Mountains (see also 1.2.3) are characterized by cretaceous deposited sandstone sediments with various features (such as hardness). Erosion and tectonic movements because of the Lusatian disturbance led to the recent landscape structure with diverse rock formations and deep valleys. The bedrock of the mountains is granodiorite. As a special feature, volcanic activity formed several numbers of hills made by basalt and phonolite. The most famous one is the Lausche (Luž, $793 \mathrm{~m}$ a.s.l.), which is the highest mountain east of the river Elbe (Labe) in Germany. Although most soils are acidic and nutrient-poor due to geology, there has been higher percentage of base saturation near the basalt and phonolite hills [18]. The mean annual amount of precipitations is $828 \mathrm{~mm}$ (Jonsdorf) [21]. The Zittauer Gebirge Mts are protected as landscape conservation area "Zittauer Gebirge" and are part of the nature park "Naturpark Zittauer Gebirge". Furthermore, the region includes two nature reserves "Lausche" and "Jonsdorfer Felsenstadt" and several natural monuments. It is partly protected as Natura 2000 habitat site (SCI) "Hochlagen des Zittauer Gebirges" [uplands of the Zittauer Gebirge Mts] and Natura 2000 bird protection site (SPA) "Zittauer Gebirge" [22]. The area is mostly covered by forest, whereby afforestation with spruce is dominant. Approximately, only $10 \%$ of the Zittauer Gebirge Mts is grassland [20]. Extensively used fresh lowland meadows with sub-montane characteristics such Bistorta officinalis and Trisetum flavescens are common. Most of them were former arable land [23] and are now predominantly classified as Festuca rubra-Agrostis capillaris meadows with high dominance of different grasses. There are some very small patches with Nardus grassland and wet meadows apparent with Dactylorhiza majalis or 
Listera ovata. Rare species are Arnica montana and the two previously mentioned orchids. Remarkably, Arnica was lost in many habitats during the last decades [24] as a result; only one site is recently known for this plant. The Zittauer Gebirge Mts have suffered extinction of many communities of typical grassland species such as Cirsium canum, C. rivulare, Coeloglossum viride, Dactylorhiza incarnata, D. sambucina, Dianthus superbus, Epipactis palustris, Eriophorum latifolium, Gymnadenia conopsea, Orchis mascula, O. morio, O. ustulata, Platanthera bifolia, and Traunsteinera globosa [24].
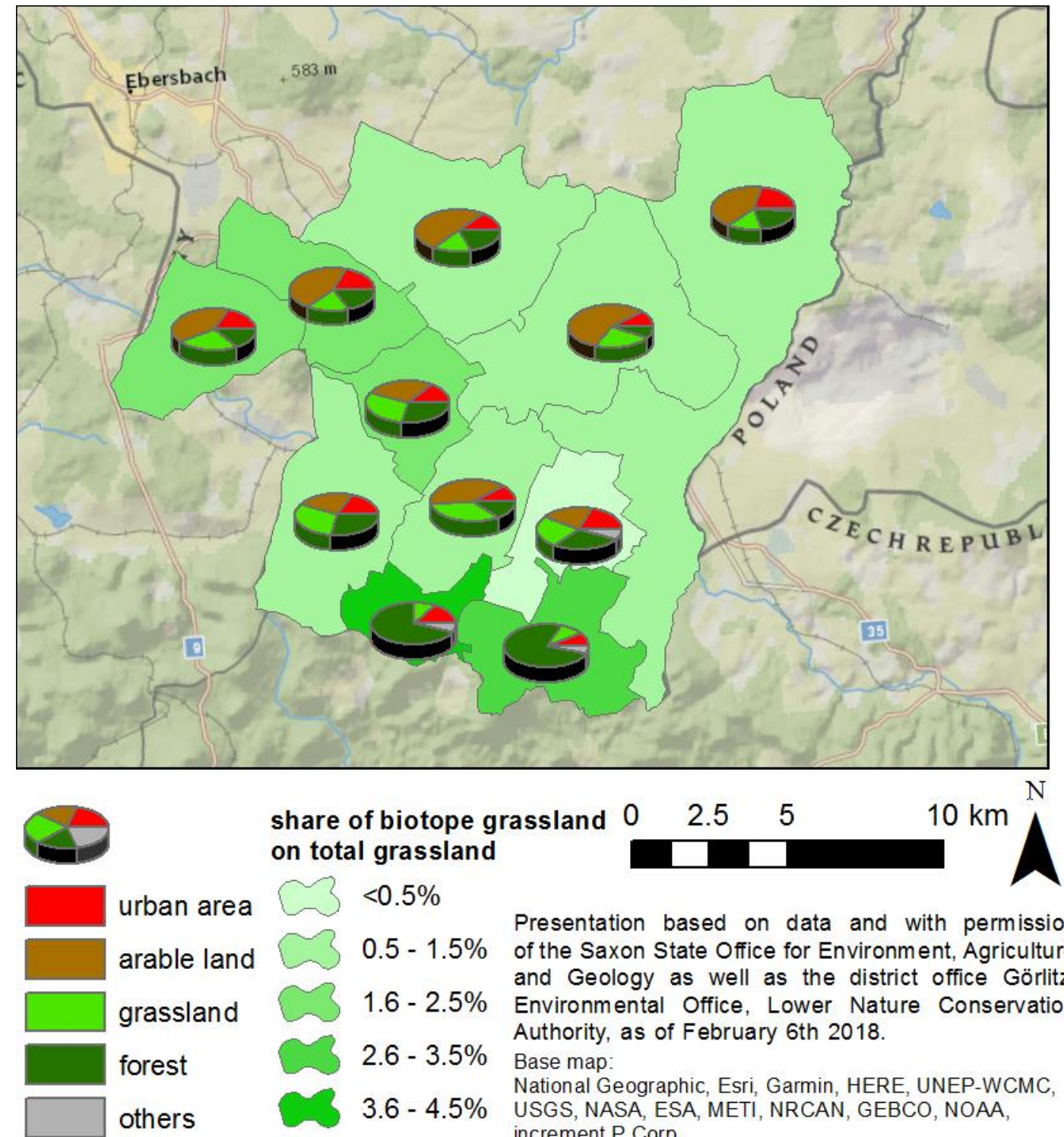

$<0.5 \%$

$0.5-1.5 \%$

Presentation based on data and with permission of the Saxon State Office for Environment, Agriculture and Geology as well as the district office Görlitz, $1.6-2.5 \%$ Environmental Office, Lower Nature Conservation $2.6-3.5 \%$ Buthority,

National Geographic, Esri, Garmin, HERE, UNEP-WCMC, $3.6-4.5 \%$ USGS, NASA, ESA, METI, NRCAN, GEBCO, NOAA increment $\mathrm{P}$ Corp

Source: [19, 20], base map: ESRI

Fig. 1: Distribution of land use and proportion of biotope grassland on total grassland in the German part (at municipality level) of the project area (source [19, 20], base map: ESRI)

The Eastern Upper Lusatia as part of the Saxon Loess-area is a very heterogeneous landscape. It shares land borders with Poland in the east, the Zittauer Gebirge Mts in the south, the Upper Lusatian Heath and Pond Landscape in the north and the Upper Lusatian Mountain Landscape in the west. Southwards, there is found the project area comprising of basins which are often covered with a loess-loam layer relatively enriched by fertile soils [18], thus promoting intensively high agricultural practices (Fig. 1) [19]. Other peculiar physical features are the intermingled basalt and phonolith hills, which structure the landscape in a distinct way as well 
as various rivers such as Mandau and Landwasser, which are tributaries of the Neiße (Nisa) [18]. The mean annual temperature is $7.9^{\circ} \mathrm{C}$ and the mean annual amount of precipitation is $630 \mathrm{~mm}$ (Olbersdorf) [21]. There are two landscape protection areas in this part of the project site. The region has four Natura 2000 habitat sites: "Mandautal" [valley of the river Mandau], "Eichgrabener Feuchtgebiet" [wetlands around the village of Eichgraben], "Separate Fledermausquartiere und -habitate in der Lausitz" (separate quaters and habitats of bats in Lusatia) and parts of "Basalt- und Phonolithkuppen der östlichen Oberlausitz" (basalt and phonolite hills in Eastern Upper Lusatia) [22]. The present grasslands are often intensively used for anthropogenic activities and species-poor Lolium-meadows dominate. Remnants of wet and dry meadows are found along small rivers and on the basalt hills respectively. On the wet sites there are found rare and typical plant species such as Dactylorhiza majalis, D. fuchsii, Sanguisorba officinalis, Laserpitium prutenicum and Succisa pratensis, though many of their communities became extinct during the last decades [24]. The semi-arid grasslands are characterized by Carex caryophyllea, Potentilla neumanniana, Rhinanthus minor, Carlina acaulis, and Orchis mascula.

\subsubsection{The Jizerské Hory Mts}

The Jizerské hory Mts, according to the geomorphological division of the Czech Republic, belong to the province Česká vysočina, Krkonošsko-jesenický system, and Krkonošský subsystem [25]. The relief of the territory was formed by tertiary tectonics and intensive weathering processes. The central part of the Jizerské hory Mts is flat with moderately high ridges and isolated hills. Flat surfaces with shallow drops, peat bogs and the edges of the mountains are cut by deep valleys of watercourses [26]. The central part of the Jizerské hory Mts is bed-rocked by granite. Based on lithology, cambisol is the dominant soil type, though cryptopodzoles, podzoles as well as peat bogs could be found in higher parts of the mountains [27]. In terms of climate, Jizera Mountains are slightly colder and richer with high precipitation. They have the mean annual temperature of $4.6^{\circ} \mathrm{C}$ and $10.3^{\circ} \mathrm{C}$ during the vegetation growing season. The mean annual amount of precipitations varies between 800 $\mathrm{mm}$ in the uplands and $1700 \mathrm{~mm}$ at the altitudes of $900 \mathrm{~m} \mathrm{[28].}$

The Protected Landscape Area (PLA) Jizerské hory Mts was established in 1968 with an area of $368 \mathrm{~km}^{2}$ [29]. Forest landscape predominantly forms this area. The most widespread forest biotopes are acidophilous beech forests, montane Calamagrostis spruce forests, bog and waterlogged spruce forests [30]. The peat bogs communities are the most valuable ones. Mesic Arrhenatherum meadows and montane Trisetum meadows are the most common grassland communities. However, there are also patches of sub-montane and montane Nardus grasslands, Cynosurus pastures, wet Cirsium meadows and wet Filipendula grasslands. At present, there are 3 national nature reserves in the Jizerské hory Mts [30]. Several rare plant species grow on non-forest biotopes in the territory of the PLA, and these include Gentianella campestris subsp. baltica, Botrychium matricariifolium, Erica tetralix, Scheuchzeria palustris, Andromeda polifolia, Lycopodiella inundata, as well as Trollius altissimus and Swertia perennis [31].

\subsubsection{The Lužické Hory Mts}

The Lužické hory Mts are located in northwest part of the Krkonošsko-jesenický system. The Lužické hory Mts were formed by tertiary volcanic activity. Another process, which formed the landscape, was due to a continental glacier. The glacier caused deposits of gravels, sands and created rubble areas. The oldest rocks of the Lužické hory Mts are granites. Majority of the territory is formed by chalk sandstones, which are tectonically bounded against granites. 
The mean annual temperature is around $7{ }^{\circ} \mathrm{C}$ and the mean annual amount of precipitation is about $800 \mathrm{~mm}[32]$.

PLA Lužické hory Mts was established in 1976 with the area of $265 \mathrm{~km} 2$ [33]. This area is determined to protect the diverse landscape of sandstone rock towns and single, trachyte and basalt cones [34]. Natural forest remnants accompanying these remarkable geomorphological formations stand in the top parts (herb-rich beech forests and ravine forests), wet mountain and sub-mountain meadows with the occurrence of rare plant species. A large part of the area includes predominantly man-made habitats. Similar to the Jizerské hory Mts, the most spread communities include mesic Arrhenatherum meadows, sub-montane and montane Nardus grasslands, Cynosurus pastures, wet Cirsium meadows and wet Filipendula grasslands. A few rare plant species are growing on grasslands in the PLA Lužické hory Mts, and they include Epipactis palustris, Gymnadenia conopsea, Drosera rotundifolia, Carex davalliana, Potamogeton alpinus, and Pedicularis sylvatica.

\subsection{History of Grassland Management in the Project Area}

Up to late Middle Age, when scythe was invented, the main grassland management had been grazing applied from early spring to late autumn. The main critical period was winter when animals were grazing in the forest, grazing woody part of shrubs and trees (shoots, bark). Additionally, the branches with dry leaves after coppicing were a source of winter forage. Consequently, since the $16^{\text {th }}$ century the creation of meadows has been associated with the use of scythes as tools for grassland cutting as it was more efficient for biomass collection than branches with leaves. This was especially practiced in wet meadows, as it was more efficient to get additional dry matter biomass. Consequently, cutting of grasslands as a source of winter forage and creating meadows started from the $17^{\text {th }}$ century. In the $18^{\text {th }}$ century a significant expansion of meadows occurred, leading to a serious deforestation in the landscape $[6,35,36$, $37,38]$.

Wide spread hay making was associated with enlargement of arable fields connected with improved three field crops system introduction. It was forced by three factors: i) increased demand for forage as cattle was used as draught animal for ploughing; ii) demand for manure as a fertilizer; iii) a suitable tool for mowing - scythe. Till the $19^{\text {th }}$ century cattle were kept in the barn during winter and grazing was applied during the whole vegetation season. In the $19^{\text {th }}$ century alternating crop management was introduced; hence instead of applying fallow grasslands were sown and used to grow fodder. This resulted in: i) closing cattle in the barn because of an increased demand for manure for field-fodder; ii) less grazing activities supported dominance of tall oat-grass (Arrhenatherum elatius); iii) municipal meadows were incorporated in crop rotations and areas of grasslands were reduced. This continued till the middle of the $20^{\text {th }}$ century and predominant land use was arable land $[6,35,36,37,38]$. For example, between 1845 and 1948, the percentage of grassland on agricultural land in the Jizerské hory Mts and the Lužické hory Mts was less than 30\% and 40\% respectively; currently they have increased drastically to about $73 \%$ and $69 \%$ respectively [39]. On the contrary, the total area of arable land shows a decreasing trend from $18 \%$ and $24 \%$ in 1845 to the current $4 \%$ and $9 \%$ for the Jizerské hory Mts and the Lužické hory Mts respectively. Similar could be said for German regions as visibly seen on historical maps [23]. Most of the grasslands were ploughed in the ' $70 \mathrm{~s}$ and ' $80 \mathrm{~s}$ and the productive clover-grass mixtures were reseeded. Intensification of agriculture led to the application of industrial fertilizers on grasslands and consequently several wet meadows were drained [36, 40]. The intensification process introduced weeds and invasive plants which are presently threats to grasslands. In the 1990s, most of these intensively managed meadows were either less intensively managed or abandoned due to a reduction in cattle heads and consequently a reduced demand for forage 
from these areas [17]. A lot of abandoned arable lands in the uplands were converted to unmanaged grasslands. Later, a considerable part of these unmanaged grasslands was managed because of the State subsidies. However, grassland management in the Czech Republic often consisted of mulching or late mowing where the harvested and packaged biomass remained at the margins of the plots to be deposited and hidden under the trees. This type of management caused a rapid decline in biodiversity in the countryside, thus valuable semi-natural meadows and pastures have become rare.

\subsection{Grasslands Status and Main Challenges in Relation to Nature Conservation in the Project Area}

On the German side of the project area the most valuable grasslands are recently managed by mini-professional nature conservation institutes with funding by the European Union within the guideline "Agrarumwelt- und Klimamaßnahmen (AUK 2015)" overseen by the Saxon State Ministry of the Environment and Agriculture [41]. Even though there were several detailed management plans for most of the top valuable sites [42, 43, 44, 45], the semi-natural grasslands are often cut only once per year in late summer without any additional management, which is sufficient to fulfill the requirements of the guideline and to receive the funding. Although the species diversity could be preserved in mid-term, this more or less rigid regime leads to a convincing support of fallow indicators like dominance of various grasses or an increase of litter layer [44, 46]. On wet sites, tall species like Filipendula ulmaria and Lysimachia vulgaris form dense dominant communities. Both effects lead to thick vegetation landscape and fewer possibilities for low competitive species to establish. According to [47], a one-cut regime is only useful for meadows with a biomass production of less than $35 \mathrm{dt} \cdot \mathrm{ha}^{-2}$ if the aim of conservation is to promote herbaceous species. Against the background of eutrophication by air, it is problematic that nitrogen is not removed effectively by cutting late in the year, as most of the plants would have already absorbed their nutrient-resources [48]. There is often no usage of the harvested material since the agricultural demand is not feasible. On valuable grassland, which is often characterized by ecological extremes such as high soil moisture or steep slopes, performing early grazing is prohibited. Aftermath grazing is just allowed with permission from the relevant authority, but without any funding [41].

On the Czech side, nature conservation in the Jizerské hory Mts and the Lužické hory Mts is currently done according to the valid care plans for these areas [30, 33]. Four zones of graduated nature conservation are defined in PLAs and different management is applied on their basis [33, 49]. It is encompassed with a network of biocentres of Territorial System of Landscape Ecological Stability connected by the bio-corridors. Maintenance mandate of PLAs is focused on the protection of their preserved natural, cultural and historical features and on the restoration of the natural functions of the landscape according to the principles of sustainable development. For the non-forest biotopes preservation, nature conservation tasks include: monitoring of sites with rare and endangered plant species and the implementation of measures to support them. It is necessary to provide appropriate care for meadow stands to preserve their maximum diversity and richness of nature communities [30]. However, it is difficult to find using for forage from species rich low-productive areas in the uplands and mountains - these areas become suitable only for afforestation or for speculation and attempts to convert them into building parcels [50]. In the protection of individual rare plant and animal species, active targeted management must be taken, selected with respect to the optimum conditions of the specific species. The care expended on the small-scale protected areas, notwithstanding, the total biodiversity of plant species is declining, and some target species either become extinct or their abundance decreases on these areas. To ameliorate this process and to increase the biodiversity of grasslands, the most suitable management methods and the best principles of conservation and restoration are needed for these habitats. 
Within the DiverGrass project, twelve experimental sites were studied. An overview of these sites is given by Fig. 2. Eight of these sites were established in 2017, in contrast the oldest site has been studied since 1998. The sites have a different history according to the land use. Nevertheless, they can serve as a model for a sustainable grassland management, which will enhance species diversity. On the sites the composition of the vegetation (summer) and the amount of above biomass (before cutting/grazing) will be recorded as well as soil samples (autumn) will be taken each year. Later it is intended to transform the sites into a long term monitoring program.

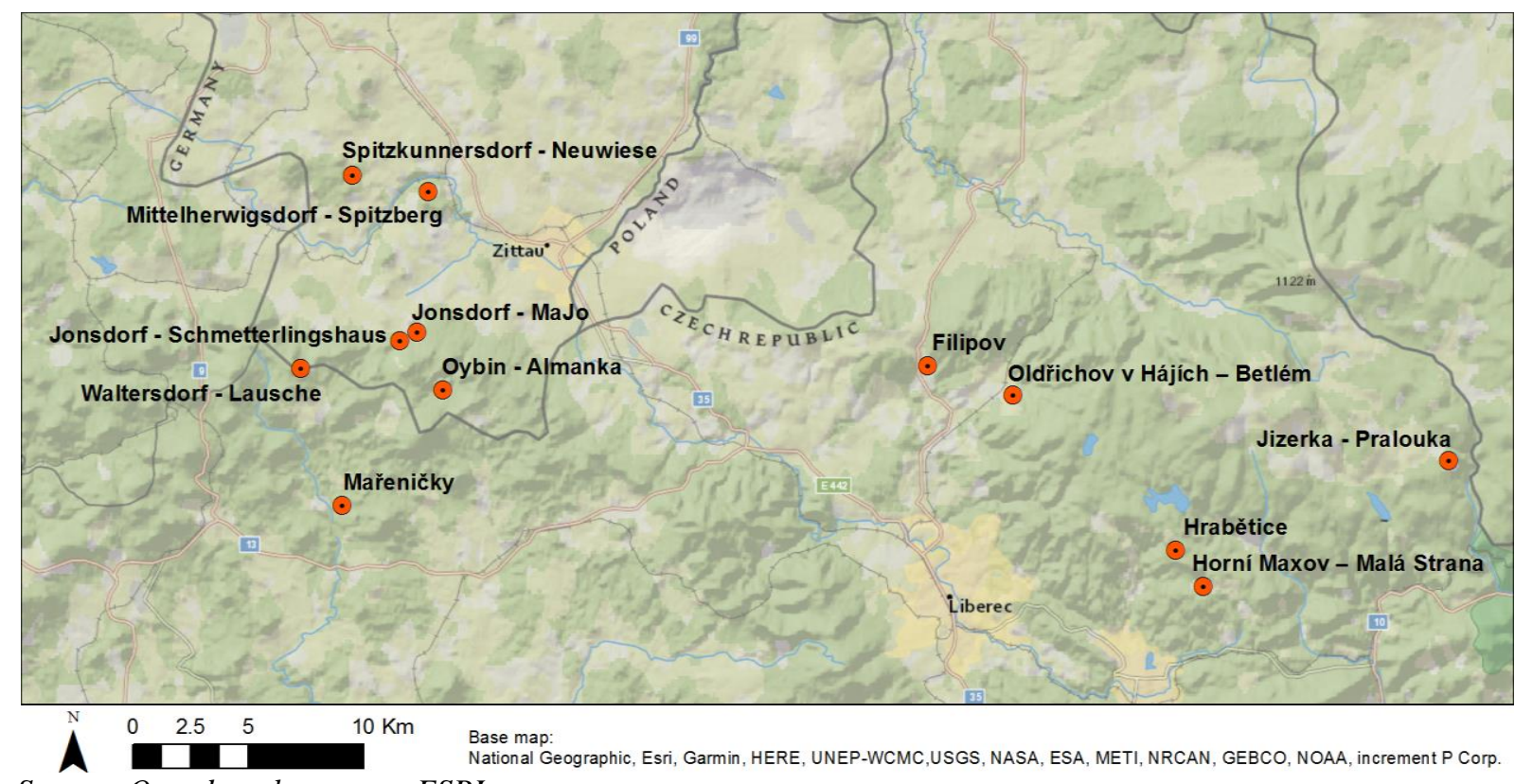

Source: Own data, base map: ESRI

Fig. 2: Location of the experimental sites of the DiverGrass project

\subsection{Horní Maxov - Malá Strana}

The experiment was established in nature reserve Malá Strana in 2005 in a wet meadow, which belonged to Calthion alliance [51], and was degraded by the expansion of Typha latifolia. The experimental treatments are no cutting, one cut per year with the removal of cut biomass in June, one cut per year with the cut biomass-litter in June, two cuts per year with the removal of cut biomass in June and August, two cuts per year with the cut biomass-litter in June and August. The study is aimed at controlling of Typha latifolia and changes in plant species composition under different cutting regimes.

\subsection{Hrabětice}

The experiment was established in 2017 in a mesophytic mountain meadow with Festuca rubra, Agrostis capillaris, Bistorta major, Cirsium heterophyllum, and Hypericum maculatum as dominant species. The meadow was annually cut in July or August with biomass removal. Oligotrophisation was remarkably found with an average number of plant species of about 20 per a $4 \mathrm{~m}^{2}$ plot. The experimental treatments are one cut early in June, one cut late in the end of August, twice cutting per year, twice cutting per year with fertilization and unmanaged grassland. The aim of the study is to compare changes in plant species composition, biomass production and functional traits under different cutting regimes and nutrients application. 


\subsection{Filipov}

The long-term mulching experiment (Fig. 3) was established in the year 2000 in the past sown meadow. Ten years before establishment of the experiment the meadow was drained, fertilized with limed and reseeded with a grass/clover of high productive mixture based on the following species: Dactylis glomerata, Festuca pratensis, Phleum pratense, Trifolium pratense, and Trifolium repens. After that it was cut twice and occasionally grazed by cattle. The plant community of the study area was classified as Arrhenatherion alliance [51] and $D$. glomerata, F. pratensis, P. pratense, Galium album, and Veronica chamaedrys were the dominant vascular plant species before the start of the study. The total number of vascular plant species was about 30 per plot $\left(24 \mathrm{~m}^{2}\right)$ in all treatments. The following treatments were applied: unmanaged control, two cuts per year with biomass removal in June and August, mulching performed once per year in July, mulching twice per year in June and August and mulching three times per year in May, July and September. This experiment is aimed at evaluating the effect of different mulching and cutting management regimes on plant species composition in a formerly improved upland meadow.

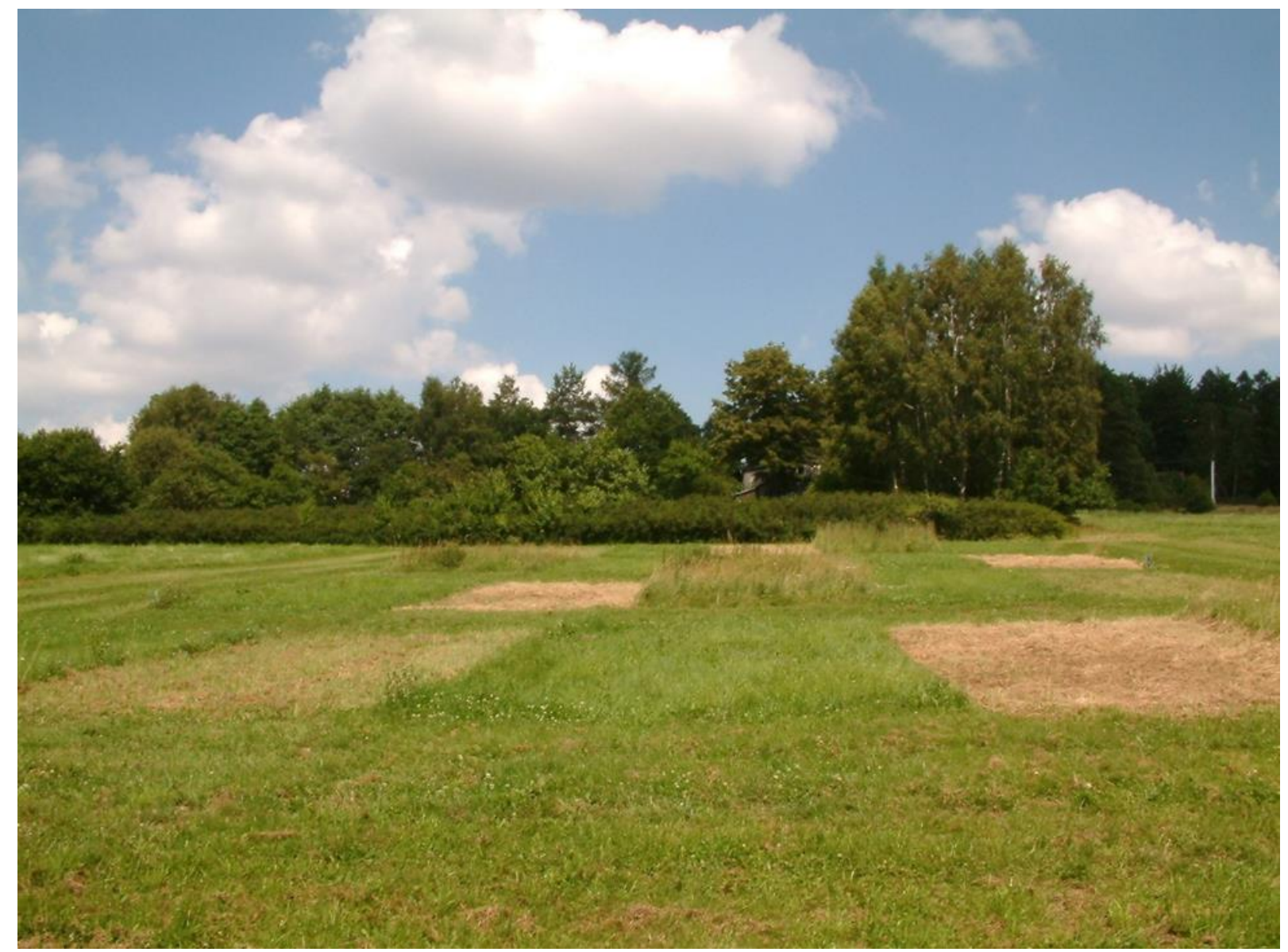

Source: Jan Gaisler

Fig. 3: Overview of the "Filipov" mulching experiment

\subsection{Mařeničky}

The experiment was established in 2017 in marginal part of natural reserve Rašeliniště Mařeničky in a mesophytic semi-natural meadow with Festuca rubra, Holcus mollis, and Agrostis capillaris as dominant species. The meadow had been unmanaged for a few years and there was visible total predominance of grasses in comparison with sporadic occurrence of dicotyledonous species. The meadow was relatively degraded and the average number of plant species was about 14 per a $4 \mathrm{~m}^{2}$ plot at the beginning of the research. The experimental 
treatments are one cut early in June, one cut late in the end of August, twice cutting per year, cutting once per two-year with fertilization and unmanaged grassland. The study is aimed at finding suitable management to enhance the increase of plant species biodiversity and support of dicotyledonous species.

\subsection{Oldřichov v Hájích - Betlém}

The long-term management experiment was established in the year 1998 on mesophytic upland grassland with dominant species such as Festuca rubra, Agrostis capillaris, and Alopecurus pratensis. The meadow was occasionally grazed a few years before the start of the experiment. On this site, the effect of heifers grazing, cutting twice per year, and abandonment on botanical composition, biomass production and structure of sward is studied (Fig. 4). Presently, an average number of plant species is about 23 on the cut, 20 on grazed and only 8 species on unmanaged plots with a size of $9 \mathrm{~m}^{2}$ each. The main aim of this experiment focused on the long-term comparison between different grassland managements and their effect on plant species composition, biomass production and soil properties.

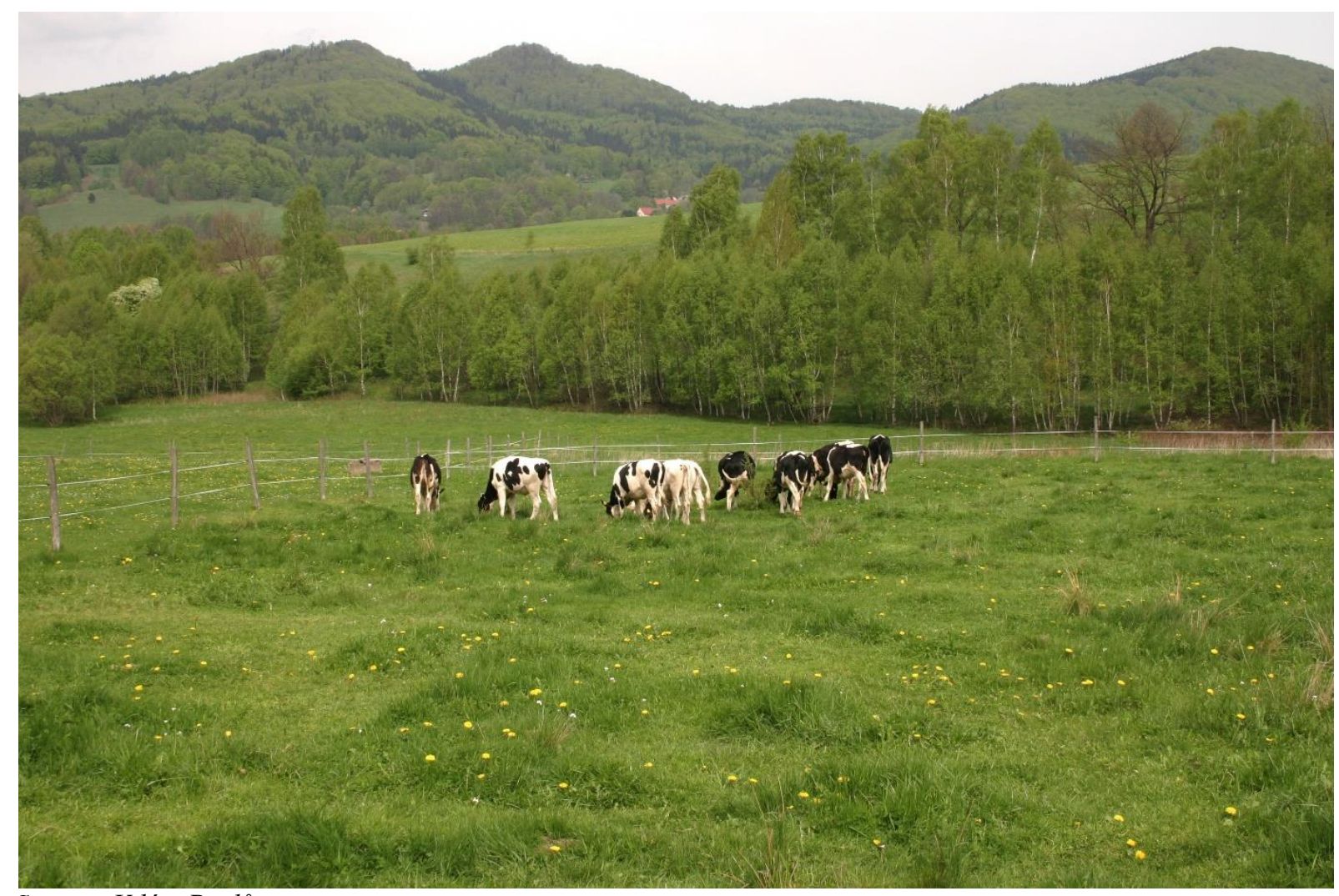

Source: Vilém Pavlů

Fig. 4: Intensively grazed pasture in "Oldřichov Grazing Experiment"

\subsection{Jizerka - Pralouka}

The experiment was established in the year 1999 in a mountain hay meadow in the Bukovec nature reserve in the north-eastern part of the Jizerské hory Mts. According to the phytosociological nomenclature [51], the vegetation of the experimental site belonged to the alliance Polygono bistortae-Trisetion flavescentis. At the beginning of the experiment, the dominant species were Festuca rubra, Agrostis capillaris, Trisetum flavescens, Cirsium heterophyllum, and Geranium sylvaticum. In 1999, the mean number of all plant species per a $25 \mathrm{~m}^{2}$ plot was about 34 . The experimental treatments are one cut per year with the removal of cut biomass in mid-July, no cutting, one cut per two years and one cut per four years 
(Fig. 5). The aim of the study is to compare long-term changes in plant species composition and functional traits under different cutting regimes.

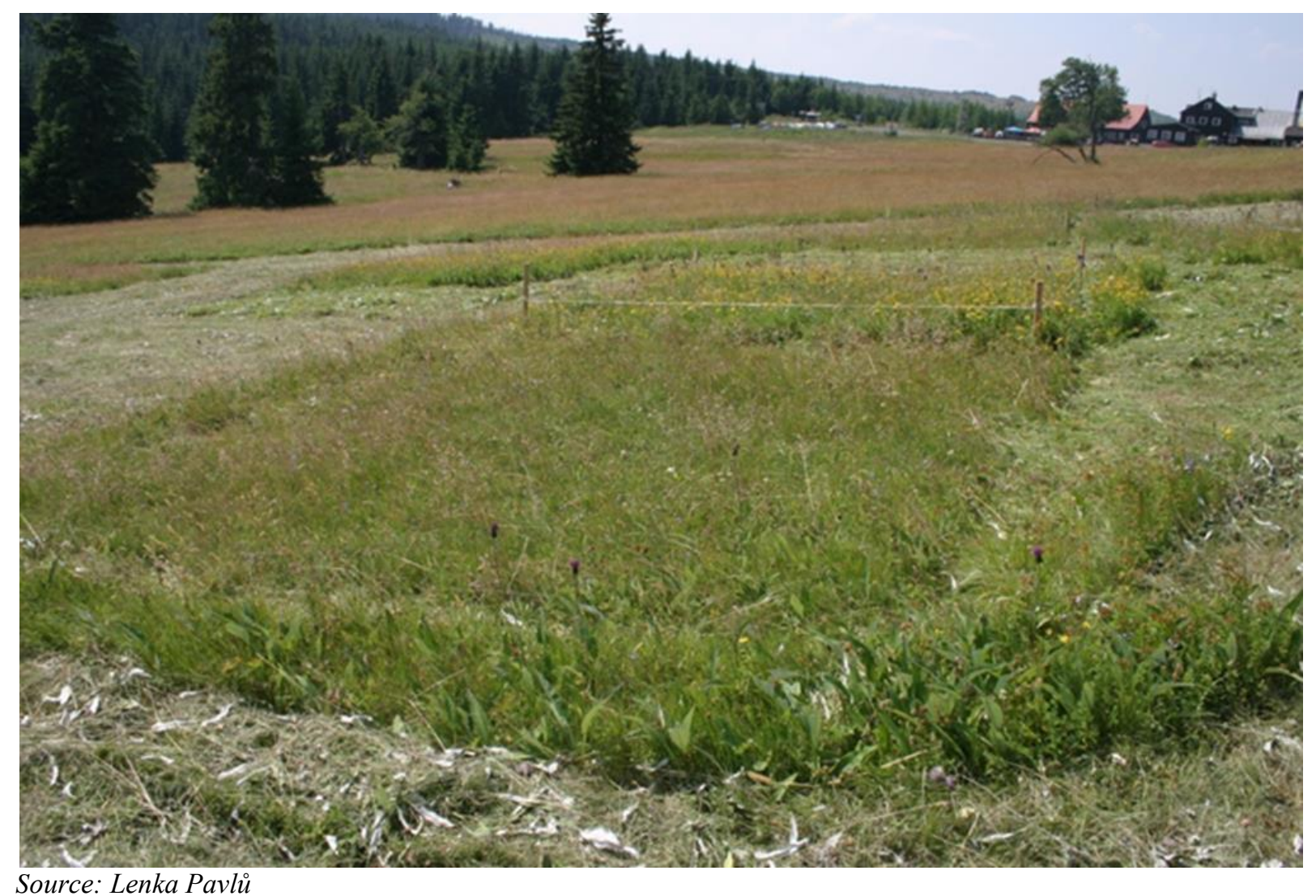

Fig. 5: One cut (on the left) and no management (on the right) treatment in "Pralouka"

\subsection{Oybin - Almanka}

The experiment was established in 2017 in a mesophytic and relatively oligotrophic upland meadow with Festuca rubra, Agrostis capillaris, Hypochaeris radicata, and Anemone nemorosa as dominant species. The meadow is cut twice annually at the end of May and in October. At present, four management treatments were established: two cuts with biomass removal, two cuts with biomass removal and liming, two cuts with biomass removal, and wood ash fertilization, two cuts with biomass removal, and with sheep dung fertilization. The average number of plant species was about 20 per a $4 \mathrm{~m}^{2}$ plot. The aim of the study is to discover suitable management to enable the increase of plant species biodiversity.

\subsection{Jonsdorf - Majo}

The experiment was established in 2017 in a species poor mesophytic and relatively oligotrophic upland meadow with Festuca rubra and Agrostis capillaris as dominant species. The meadow is cut annually in late summer and there is a minimal amount of available soil phosphorus due to management applied in the past ( 5 cuts per year). Two treatments were established: present management (one late cut in September/October) and cut with $\mathrm{P}+\mathrm{K}$ fertilization. The average number of plant species was about 18 per a $4 \mathrm{~m}^{2}$ plot. The study is aimed at discovering suitable management for the increase of plant species biodiversity.

\subsection{Jonsdorf - Schmetterlingshaus}

The experiment was established in 2017 in a relatively wet upland meadow (Fig. 6) with Carex brizoides and Bistorta officinalis as dominant species. The meadow is annually cut in 
late summer. Four treatments were established: present management (one late cut), two cuts (mid-June and mid-August), two cut and hay transfer (donation site Leutersdorfer Folge), two cut and soil disturbance (milling) and hay transfer. The average number of plant species was about 28 per a $4 \mathrm{~m}^{2}$ plot. The aim of the study is to discover suitable management for the increase of plant species biodiversity and development of species rich wet meadow.

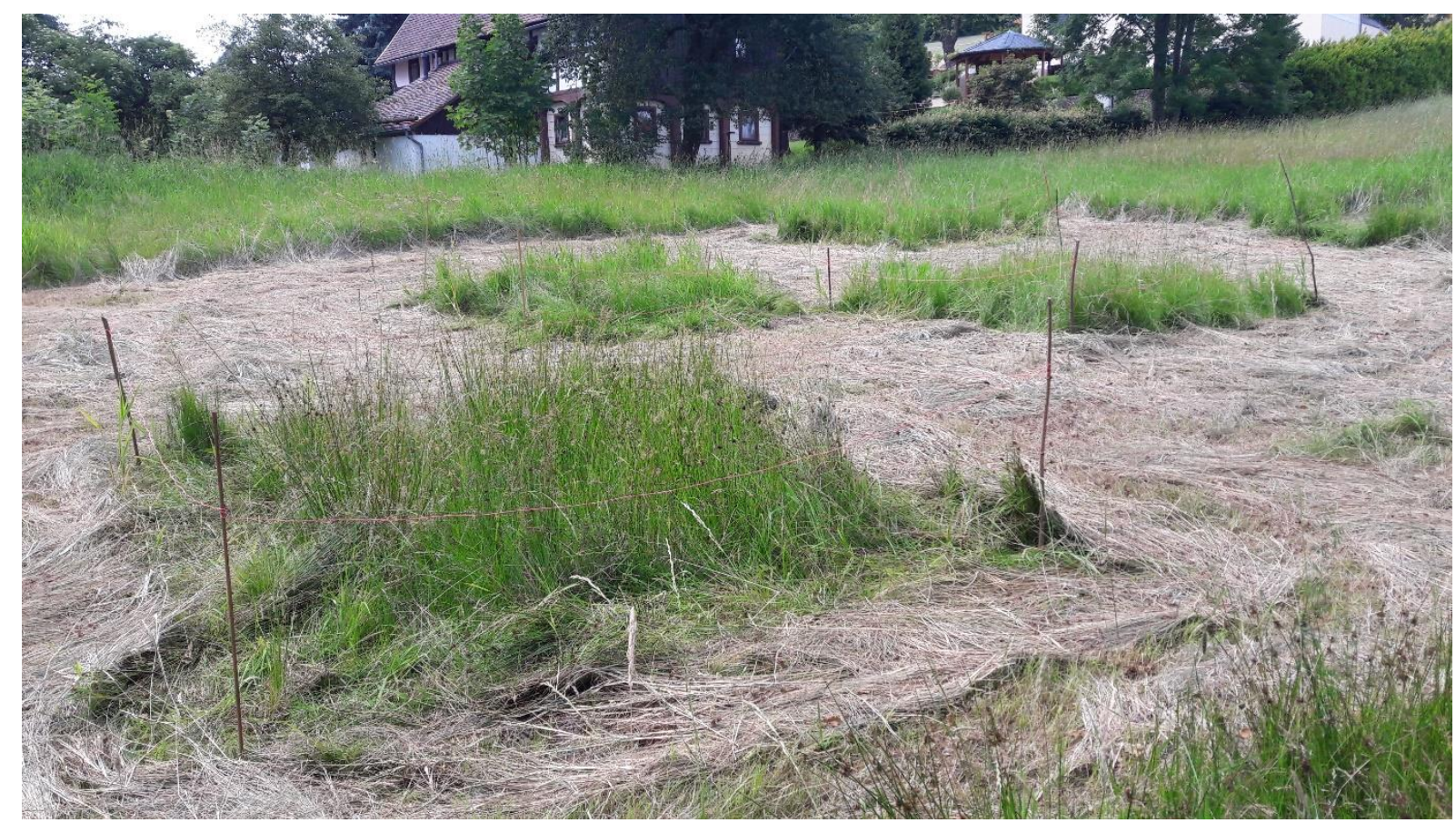

Source: Henning Haase

Fig. 6: Experiment in meadow "Schmetterlingshaus" after first cutting in June 2017

\subsection{Waltersdorf - Lausche}

The experiment was established in 2017 in a species-poor mesophytic mountain meadow with Festuca rubra, Holcus mollis, and Agrostis capillaris as dominant species. It has low species diversity with about 12 species per a $4 \mathrm{~m}^{2}$ plot. The meadow is cut annually in late summer and there is a minimal amount of available soil phosphorus. Four treatments were established: present management (one cut in August), one cut with hay transfer (donation site: species rich meadow nearby), one cut with hay transfer and disturbance (raking), one cut with hay transfer and top-soil removal (Fig. 7). The aim of the study is to find suitable management for increase of plant species biodiversity.

\subsection{Spitzkunnersdorf - Neuwiese}

The experiment was established in 2017 in a fresh wet forest meadow with high dominance of Carex brizoides. In the locality some members of Orchidaceae family exist. This area was cut in the past as a part of a big meadow complex until the 1940s [23]. Probably in the 1950s, the biggest part was afforested and the meadow in recent dimensions was left [52]. After 2010 it was abandoned for a few years. Presently, the meadow is cut annually in late term. Two treatments were established: present management (one late cut) and two cuts in the beginning of June and August. The average number of plant species was about 23 per a $4 \mathrm{~m}^{2}$ plot. The aim of the study is to find suitable management for the increase of plant species biodiversity especially of target species like Dactylorhiza fuchsii and to reduce the dominance of Carex brizoides. 


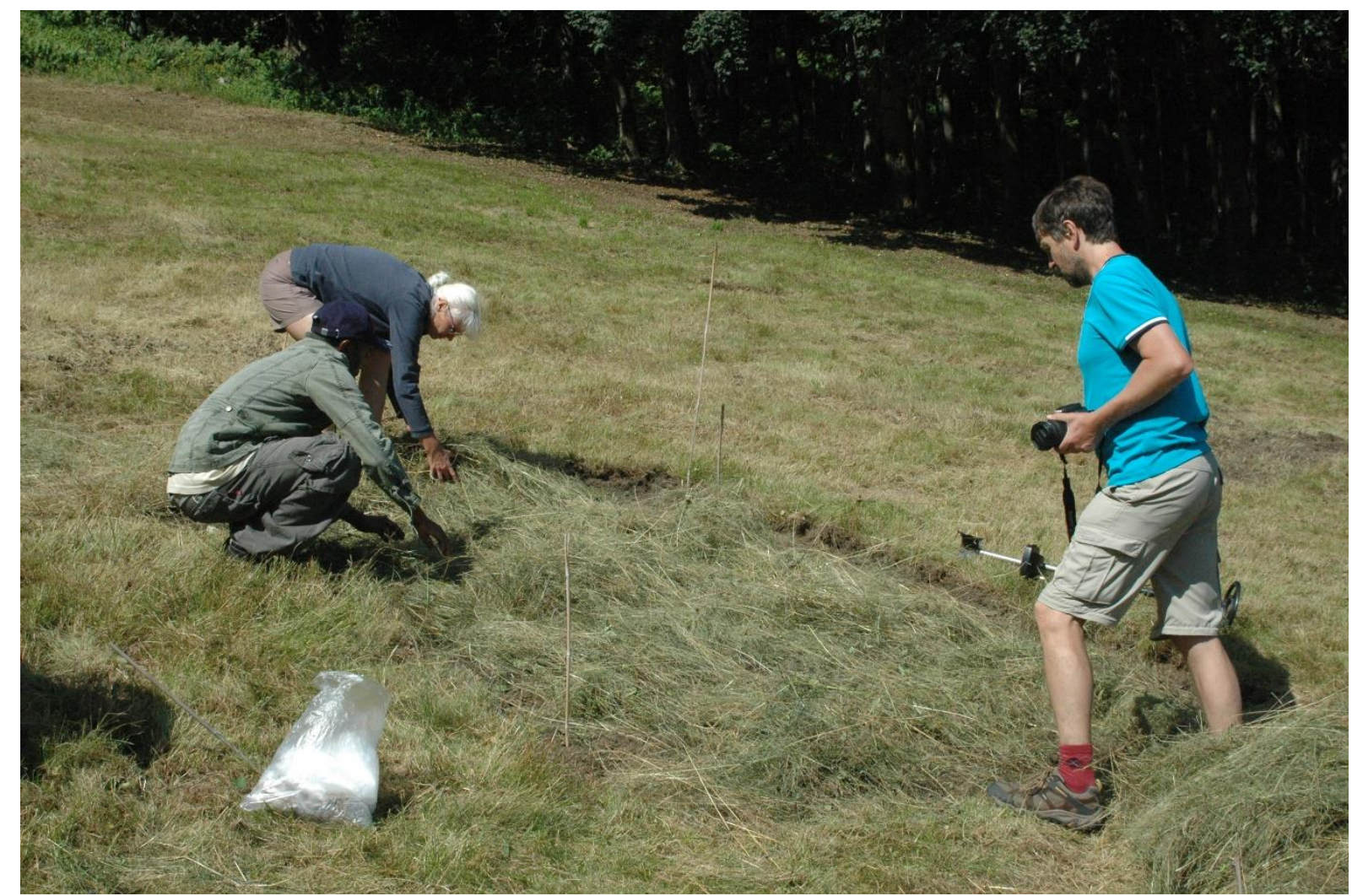

Source: Henning Haase

Fig. 7: Hay transfer at Lausche

\subsection{Mittelherwigsdorf - Spitzberg}

The experiment was established in 2017 on a basalt hill. Although the meadow has still Festuca rubra and Agrostis capillaris as dominant species, relatively rich occurrence of the rare species such as Carlina acaulis, subsp. acaulis are found. This area had been grazed by sheep and goats until the middle of the $20^{\text {th }}$ century when it was converted to an intensive pasture for cattle; and after the change in political leadership it was abandoned for a few years [44]. Now, the meadow is cut yearly in late term. There is a dense $(\sim 10 \mathrm{~cm})$ layer of rotten material which prevents establishment of low competitive species. Additionally, there are signs of acidification (Vaccinium myrtillus) which are not typical for this kind of a meadow. Two treatments were established: present management (one late cut in September) and early cut (in June) followed by sheep grazing (Fig. 8). The average number of plant species was about 26 per a $4 \mathrm{~m}^{2}$ plot. The study is aimed at discovering suitable management for promoting some herbaceous target species and to change the current structure of the sward for an enriched sward. 


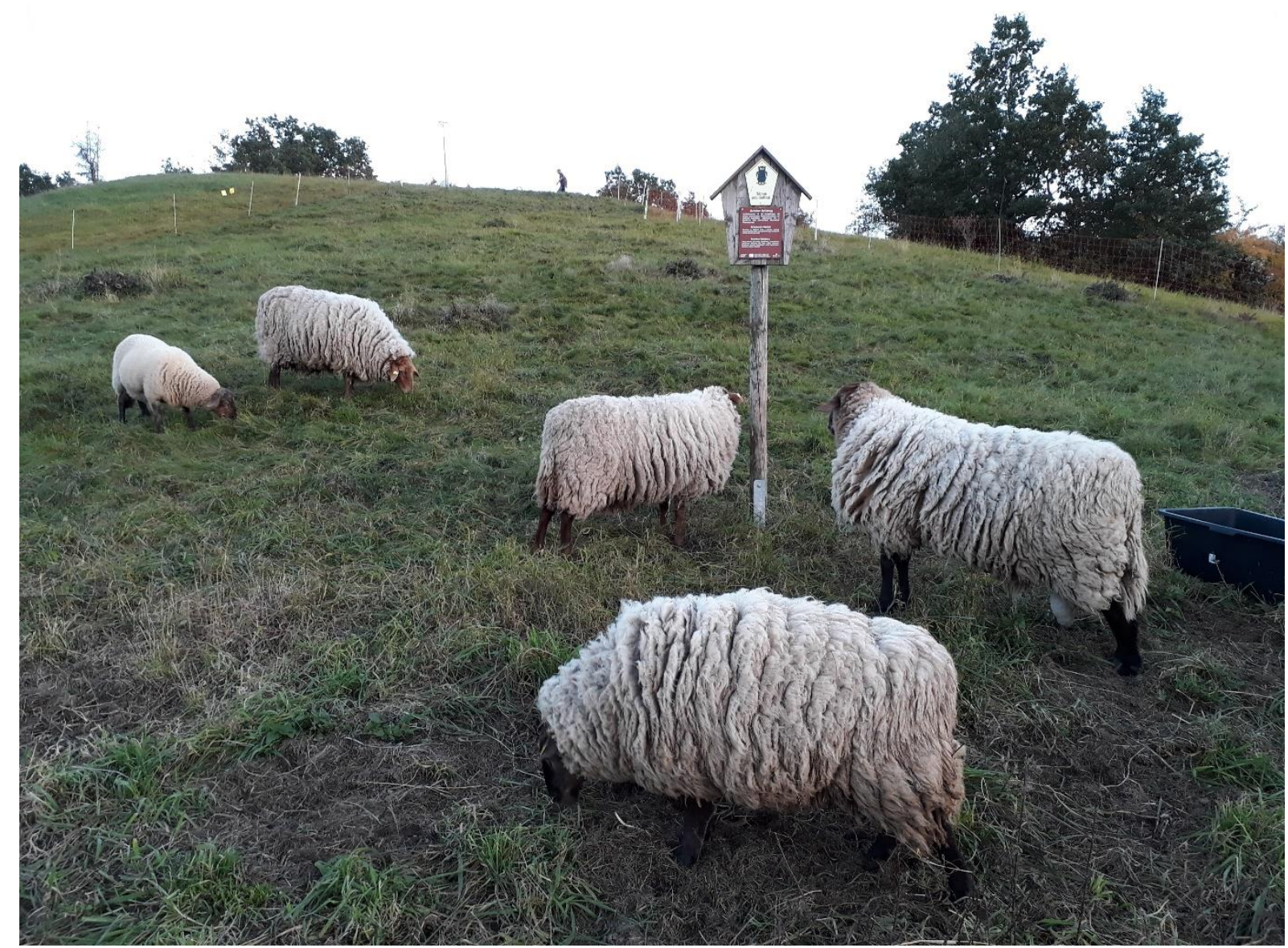

Source: Henning Haase

Fig. 8: Aftermath grazing at Spitzberg

\section{Conclusion}

The cross-border area comprising the Jizerské hory Mts (CZ), the Lužické hory Mts (CZ) and the Zittauer Gebirge Mts (D) had similar historical land use and nowadays there are similar problems in nature conservation in relation to grasslands plant species diversity. Despite various subsidies, there is a remarkable decrease of plant species diversity in grasslands habitats. In the view of these, twelve manipulative management experiments were established in DiverGrass project on different types of grasslands to find long term sustainable management supporting plant species diversity.

\section{Acknowledgements}

The described project is funded by the program Interreg VA SN-CZ 2014-2020, Nr. 100264999.

\section{Literature}

[1] HEYWOOD, V. H. (ed.) Global Biodiversity Assessment. Cambridge University Press, Cambridge, 1995.

[2] BUTCHART, S. H. M.; WALPOLE, M.; COLLEN, B.; Van STRIEN, A.; SCHARLEMANN, J. P. W.; ALMOND, R. E. A.; BAILLIE, J. E. M.; BOMHARD, B.; BROWN, C.; BRUNO, J.; CARPENTER, K. E.; CARR, G. M.; CHANSON, J.; CHENERY, A. M.; CSIRKE, J.; DAVIDSON, N. C.; DENTENER, F.; FOSTER, M.; GALlI, A.; GALLOWAY, J. N.; GENOVESI, P.; GREGORY, R. D.; HOCKINGS, 
M.; KAPOS, V.; LAMARQUE, J.-F.; LEVERINGTON, F.; LOH, J.; McGEOCH, M. A.; McRAE, L.; MINASYAN, A.; MORCILLO, M. H.; OLDFIELD, T. E. E.; PAULY, D.; QUADER, S.; REVENGA, C.; SAUER, J.; SKOLNIK, B.; SPEAR, D.; STANWELL-SMITH, D.; STUART, S. N.; SYMES, A.; TIERNEY, M.; TYRRELL, T. D.; VIÉ, J.-Ch.; WATSON, R.: Global biodiversity: Indicators of recent declines. Science. 2010, Vol. 328, Issue 5982. DOI: $10.1126 /$ science. 1187512

[3] GOSSNER, M. M.; LEWINSOHN, T. M.; KAHL, T.; GRASSEIN, F.; BOCH, S.; PRATI, D.; BIRKHOFER, K.; RENNER, S. C.; SIKORSKI, J.; WUBET, T.; ARNDT, H.; BAUMGARTNER, V.; BLASER, S.; BLÜTHGEN, N.; BÖRSCHIG， C.; BUSCOT, F.; DIEKÖTTER, T.; RÉ, J. L.; JUNG, K.; KEYEL, A. C.; KLEIN, A.-M.; KLEMMER, S.; KRAUSS, J.; LANGE, M.; MÜLLER, J.; OVERMANN, J.; PAŜALIĆ, E.; PENONE, C.; PEROVIĆ, D. J.; PURSCHKE, O.; SCHALL, P.; SOCHER, S. A.; SONNEMANN, I.; TSCHAPKA, M.; TSCHARNTKE, T.; TÜRKE, M.; VENTER, P. C.; WEINER, C. N.; WERNER, M.; WOLTERS, V.; WURST, S.; WESTPHAL, C.; FISCHER, M.; WEISSER, W. W.; ALLAN, E.: Land-use intensification causes multitrophic homogenization of grassland communities. Nature. 2016, Vol. 540, pp. 266-269. DOI: 10.1038/nature20575

[4] HETTWER, C.; ZÖPHEL U.; WARNKE-GRÜTTNER, R.: Zustand der Arten und Lebensraumtypen zur FFH-Richtlinie in Sachsen 2007-2012. Naturschutzarbeit in Sachsen. 2015, Vol. 57, pp. 4-23.

[5] RYCHNOVSKÁ, M. (ed.): Structure and functioning of seminatural meadows. Elisevier Science Publisher, Amsterdam, 1993. ISBN 978-0-444-98669-6. ISSN 01662287. DOI: $\underline{10.1016 / \mathrm{c} 2009-0-01045-9}$

[6] BOSSHARD, A.: Das Naturwiesland der Schweiz und Mitteleuropas. Haupt Verlag, Bern, 2016. ISBN 978-3-258-07973-8.

[7] DIERSCHKE, H.; BRIEMLE, G.: Kulturgrasland - Wiesen, Weiden und verwandte Staudenfluren. Ulmer, Stuttgart, 2002. ISBN 3-8001-3816-6.

[8] JONGEPIEROVÁ, I.; PEŜOUT, P.; JONGEPIER, J. W.; PRACH, K.: Ecological restoration in the Czech Republic. Nature Conservation Agency of the Czech Republic, České Budějovice, 2012. ISBN 978-80-87457-32-0.

[9] HEJCMAN, M.; HEJCMANOVÁ, P.; PAVLŮ, V.; BENEŠ, J.: Origin and history of grasslands in Central Europe - a review. Grass and Forage Science. 2013, Vol. 68, Issue 3, pp. 345-363. DOI: $10.1111 /$ gfs.12066

[10] SMIT, H. J.; METZGER, M. J.; EWERT, F.: Spatial distribution of grassland productivity and land use in Europe. Agricultural Systems. 2008, Vol. 98, Issue 3, pp. 208-219. DOI: $10.1016 /$ j.agsy.2008.07.004

[11] ROOK, A. J.; DUMONT, B.; ISSELSTEIN, J.; OSORO, K.; WALLISDEVRIES, M. F.; PARENTE, G.; MILLS, J.: Matching type of livestock to desired biodiversity outcomes in pastures: a review. Biological Conservation. 2004, Vol. 119, Issue 2, pp. 137-150. DOI: 10.1016/j.biocon.2003.11.010

[12] PÄRTEL, H.; BRUUN, H. H.; SAMMUL, M.: Biodiversity in temperate European grasslands: origin and conservation. In: Lillak, R.; Viiralt, R.; Linke, A.; Geherman, V. (eds.), Integrating efficient grassland farming and biodiversity. Estonian Grassland Society, Tartu, 2005, pp. 1-14. ISBN 9985-9611-3-7. 
[13] PAVLŮ, V.; HEJCMAN, M.; PAVLU゚, L.; GAISLER, J.; NEŽERSKOVÁ, P.; GUEROVICH, P.; ANDALUZ, M.: Vegetation changes after cessation of grazing management in the Jizerské Mountains (Czech Republic). Annales Botanici Fennici. 2005, Vol. 42, pp: 343-349. ISSN 0003-3847.

[14] HEJCMAN, M.; KLAUDiSOVÁ, M.; HEJCMANOVÁ, P.; PAVLŮ, V.; JONES, M.: Expansion of Calamagrostis villosa in sub-alpine Nardus stricta grassland: Cessation of cutting management or high nitrogen deposition? Agriculture, Ecosystems \& Environment. 2009, Vol. 129, Issues 1-3, pp. 91-96. DOI: 10.1016/j.agee.2008.07.007

[15] KRISTENSEN, T.; SØEGAARD, K.; KRISTENSEN, I. S.: Management of grasslands in intensive dairy livestock farming. Livestock Production Science. 2005, Vol. 96, Issue 1, pp. 61-73. DOI: 10.1016/j.livprodsci.2005.05.024

[16] ISSELSTEIN, J.; JEANGROS, B.; PAVLŮ, V.: Agronomic aspects of biodiversity targeted management of temperate grasslands in Europe - A review. Agronomy Research. 2005, Vol. 3, Issue 2, pp. 139-151.

[17] PAVLŮ, V.; HEJCMAN, M.; PAVLU゚, L.; GAISLER, J.: Restoration of grazing management and its effect on vegetation in an upland grassland. Applied Vegetation Science. 2007, Vol. 10, Issue 3, pp. 375-382. DOI: 10.1111/j.1654109X.2007.tb00436.x

[18] MANNSFELD, K.; RICHTER, H.: Naturräume in Sachsen. In: Richter, G (ed.) Forschungen zur deutschen Landeskunde. Trier, 1995, Vol. 238, pp. 1-230. ISBN: 388143-049-0.

[19] SÄCHSISCHES LANDESAMT FÜR UMWELT, LANDWIRTSCHAFT UND GEOLOGIE (LfULG): Biotoptypen- und Landnutzungskartierung (BTLNK). 2005. Available from WWW: https://www.umwelt.sachsen.de/umwelt/natur/25140.htm

[20] LANDRATSAMT GÖRLITZ, UMWELTAMT, UNTERE NATURSCHUTZBEHÖRDE (UNB Görlitz) (2018): Gesetzlich geschützte Biotope im Landkreis Görlitz, Stand 06.02.2018.

[21] METEROLOGISCHER DIENST DER DEUTSCHEN DEMOKRATISCHEN REPUBLIK: Klimatologische Normalwerte 1951/80. Klimadaten der Deutschen Demokratischen Republik - Ein Handbuch für die Praxis. 1987, Vol. 14, pp. 1-111.

[22] Schutzgebiete. In: Landkreis Görlitz. Geoportal Online. [online]. Landratsamt Görlitz, 2015. [accessed 2018-03-06]. Available from WWW: http://gis-lkgr.de/

[23] Topographische Karte (Meßtischblätter) Sachsen. Abteilung für Landesaufnahme des Königl. Sächs. Generalstabes. - 1:25000. - 156 Blatt, versch. Auflagen 1905-1942. Leipzig. - Je Bl. 48 x $45 \mathrm{~cm}$. In: Deutsche Fotothek [online]. Sächsische Landesbibliothek - Staats- und Universitätsbibliothek Dresden (SLUB DRESDEN), 2007. [accessed 2018-03-06]. Avaiable from WW: http://www.deutschefotothek.de/cms/kartenforum-sachsen-messtischblaetter-alt.xml

[24] RICHTER, F.; SCHULZ, D.: Farn- und Samenpflanzen - Bestandssituation und Schutz ausgewählter Arten in Sachsen. Sächsisches Landesamt für Umwelt, Landwirtschaft und Geologie, Dresden, Vol. 2, 2016.

[25] DEMEK, J.; MACKOVČIN, P: Zeměpisný lexikon ČR. Hory a nižiny. AOPK, Brno, 2006. ISBN 80-86064-99-9.

[26] DEMEK, J.: Hory a nižiny. Nakladatelství Academia, Praha, 1987. 
[27] TOMÁŠEK, M.: Půdní mapa ČR (1:50 000). List 03-14 Liberec, 1995. Český geologický ústav, Praha.

[28] KULASOVÁ, A.; BUBENÍČKOVÁ, L.: Podnebí a počasí Jizerských hor. In: Karpaš R et al (eds.), Jizerské hory, O mapách, kamení a vodě. Nakladatelství RK, Liberec, 2009. pp 344-367. ISBN 978-80-87100-08-0.

[29] VETEŠNÍK, P.; VONIČKA, P.: Správa Chráněné krajinné oblasti Jizerské hory. Sborník Severočeského muzea. Severočeské muzeum, Liberec, 1999, Vol. 21, pp. 247252. ISBN 80-238-3934-9.

[30] AOPK ČR: Plán péče o Chráněnou krajinnou oblast Jizerské hory na obdobi 2011 2020. AOPK ČR, SCHKO Liberec, 2010.

[31] VIŠŇÁK, R.: Rostlinstvo Jizerských hor. In: Karpaš R.; Višňák R.; Vonička P. (eds.), Jizerské hory - o rašeliništich, květeně a zvíreně. Nakladatelství RK, Liberec, 2013, pp. 73-169. ISBN 978-80-87100-23-3.

[32] PECH, P.: Landforms and Rock Formations in Lusatian. Liberec, Bachelor thesis. Technická univerzita v Liberci. 2012.

[33] AOPK ČR: Plán péče o CHKO Lužické hory na obdobi 2015-2024. AOPK ČR, SCHKO Liberec, 2013.

[34] Chráněná krajinná oblast Lužické hory. In: Wikipedia. [encyclopedia online]. Wikimedia Foundation Inc., updated 10 February 2018, at 22:14. [accessed 2018-0223]. Available from https://cs.wikipedia.org/wiki/Chráněná_krajinná_oblast_Lužické_hory

[35] KAUTER, D.: "Sauergras" und "Wegbreit" - Die Entwicklung der Wiesen in Mitteleuropa zwischen 1500 und 1900. Berichte des Institutes für Landschafts- und Pflanzenökologie der Universität Hohenheim, Stuttgart, 2002. ISBN 3-935380-05-4.

[36] HEMPEL, W.: Die historische Entwicklung des Wirtschaftsgrünlandes in Sachsen. Berichte der Naturforschenden Gesellschaft der Oberlausitz. 2008, Vol. 16, pp. 3-18. ISSN 0941-0627.

[37] POSCHLOD, P.: Geschichte der Kulturlandschaft. Ulmer, Stuttgart (Hohenheim), 2015. ISBN 978-3-8001-7983-1.

[38] HEJCMAN, M; PAVLŮ, V.: Historie pastevního obhospodařování (History of grazing management). In: Mládek J.; Pavlů V.; Hejcman M.; Gaisler J. (eds.), Pastva jako prostředek údržby trvalých travních porostů $v$ chráněných územích (Grazing as a method of grasslands management in protected areas). VÚRV, Praha, pp. 7-9. ISBN 80-86555-76-3.

[39] Aplikace pro prohlížení naskenovaných archiválií. In: Ústřední Archiv Zeměměřictví a Katastru (Úazk) [online]. 2017, Český Úřad Zeměměřičský a Katastrální. [accessed 2017-04-23]. Available from http://archivnimapy.cuzk.cz/uazk/pohledy/archiv.html

[40] GAISLER, J.; HEJCMAN, M.; MIKULKA, J.; PAVLŮ, L.; PAVLU゚, L.; ŠTROBACH, J.: Zemědělské využívání krajiny. In: Karpaš R.; Hušek J. (eds.), Jizerské hory o lesích, dřevu a ochraně prírody. Nakladatelství RK, Liberec, 2014, pp. 498-507. ISBN 97880-87100-26-4. 
[41] SÄCHSISCHES MINISTERIUM FÜR UMWELT UND LANDWIRTSCHAFT (SMUL) Richtlinie des Sächsischen Staatsministeriums für Umwelt und Landwirtschaft zur Förderung von Vorhaben der umweltgerechten Flächenbewirtschaftung im Freistaat Sachsen (Förderrichtlinie Agrarumwelt- und Klimamaßnahmen - RL AUK/2015). [online] 2015. [accessed 2018-03-06]. Available from WWW: https://www.revosax.sachsen.de/vorschrift/16239/25377

[42] BUSCHMANN, P.: Dokumentation und Pflegerichtlinie für das Flächennaturdenkmal Hänschberg am Kottmar. Unpublished investigation, 1987.

[43] GLÄSER, P.: Zustandserfassung und Behandlungsrichtlinien für ausgewählte Landschaftspflegeobjekte im Landkreis Löbau-Zittau (2004). Unpublished investigation, Bautzen, 2004.

[44] LANDSCHAFTSARCHITEKTURBÜRO SCHÜTZE UND PARTNER: Managementplan für das pSCI 113 „,Mandautal“. Unpublished investigation, Bautzen, 2004.

[45] JANSEN \& PARTNER: Managementplan für das SCI 032E „Hochlagen des Zittauer Gebirges “. Unpublished investigation, Bautzen, 2006.

[46] BUNDESAMT FÜR NATURSCHUTZ (BFN): ...Grünlandnutzung nicht vor dem 15. Juni... Sinn und Unsinn von behördlich verordneten Fixterminen in der Landwirtschaft. Dokumentation einer Tagung des Bundesamtes für Naturschutz und des NaturschutzZentrums Hessen (NZH) in Wetzlar am 16. / 17. September 2003. BfN-Skripten. 2004, Vol. 124, pp. 1-90

[47] BRIEMLE, G.: Landschaftsökologisch sinnvolle Mindestpflege von artenreichem Grünland und dessen erfolgsorientierte Bewertung. In: Reiter, K.; Schmidt, A.; Stratmann, U. (eds) ...Grünlandnutzung nicht vor dem 15. Juni.... BfN-Skripten, Vol. 124, Bonn, Bad-Godesberg, 2004. pp. 33-56.

[48] NITSCHE, S.; NITSCHE, L.: Extensive Grünlandnutzung. Neumann, Radebeul, 1994, ISBN 978-3740201494.

[49] HUŠEK, J.: Zonace území CHKO Jizerské hory. In: Karpaš R.; Hušek J. (eds.), Jizerské hory - o lesích, dřevu a ochraně přirody. Nakladatelství RK, Liberec, 2014. ISBN 97880-87100-26-4.

[50] HUŠEK, J.: Jizerské hory. Ochrana př́rody. 2008, Vol. 63, Issue 3, pp. 2-5. ISSN 1210-258X.

[51] Katalog biotopů. In: Katalog biotopů České republiky. [online]. AOPK, 2010, AOPK. [accessed 2018-02-21]. Available from WWW: http://geoportal.gov.cz/web/guest/home

[52] Topographische Karte 1 : 25000 - Ausgabe Staat (DDR). In: GeoViewer.Sachsen [online]. Staatsbetrieb Geobasisinformation und Vermessung, 2017. [accessed 2018-0306]. Avaiable from WWW: https://geoviewer.sachsen.de/mapviewer2/index.html?map=359463cd-0222-49ba-bad2c9f84a6fb1ca\&lang=de

Ing. Jan Titěra; Henning Haase, MSc; Ing. Teowdroes Kassahun Teka;

Ing. Chukwudi Nwaogu, MSc; Ing. Klára Pavlů, Ph.D.; Dr. Matthias Kändler;

Ing. Lenka Pavlů, Ph.D.; Ing. Jan Gaisler, Ph.D.; František Paška; Heike Heidenreich;

Dipl.-Ing (FH) Gerlinde Liepelt; Irena Jonášová; Prof. Dr. Vilém Pavlů 


\section{DIVERGRASS - PřESHRANIČNÍ PROJEKT PRO PODPORU UDRŽITELNÉHO MANAGEMENTU TRAVNÍCH POROSTU}

Většina evropských luk a pastvin patří k polopřirozeným nebo dočasným intenzivním travním porostům. Poloprirozené, většinou druhově bohaté travní porosty byly po staletí udržovány pomocí zemědělských aktivit. Nicméně, $\mathrm{v}$ dnešní době jsou modernějším, ale rozšířeným jevem intenzivní travní porosty. Pastva skotu je klíčovým způsobem obhospodařování pro pastviny a pravidelné sečení pro louky. Kombinace pasení a sečení je typická pro spásané louky. Absence defoliace travních porostů, extenzifikace nebo př́liš intenzivní hospodaření může vést $\mathrm{k}$ poklesu druhové diverzity, doprovázeným mizením ohrožených druhů rostlin. Snižování druhové rozmanitosti travních porostů na přírodních stanovištích je jedním z klíčových problémů současné ochrany prírody na obou stranách česko-německé hranice. V přeshraniční oblasti zahrnující Jizerské hory (CZ), Lužické hory (CZ) a Zittauer Gebirge $\mathrm{s}$ předhůř́m (D) bylo $\mathrm{v}$ rámci projektu DiverGrass na různých typech travních porostů založeno 12 manipulativních managementových experimentů $\mathrm{s}$ cílem nalézt optimální opatření pro zastavení poklesu nebo zvýšení biodiverzity rostlin na stanovištích s travními porosty.

\section{DIVERGRASS - EIN GRENZÜBERGREIFENDES PROJEKT ZUR FÖRDERUNG NACHHALTIGEN MANAGEMENTS VON GRASLAND}

Der Großteil der europäischen Wiesen und Weiden kann dem halbnatürlichen Grasland oder dem eingesäten Intensiv-Grasland zugeordnet werden. Halbnatürliches oft artenreiches Grasland entstand aus der jahrhundertelangen landwirtschaftlichen Tätigkeit des Menschen. Intensiv-Grasländer hingegen sind eine relativ moderne aber sehr weit verbreitete Erscheinung. Während die Beweidung für Weiden typisch ist und regelmäßiges Mähen für Wiesen, wird bei Mähweiden die Mahd mit einer Vor- oder Nachbeweidung kombiniert. Die Nutzungsaufgabe, zu extensive oder zu intensive Nutzung führt in der Regel zu einer Reduktion der Pflanzenvielfalt und Verlust von gefährdeten Pflanzenarten. Der Verlust der Diversität halbnatürlicher Grasländer ist derzeit eines der größten Probleme des Naturschutzes beiderseits der Deutsch (D)-Tschechischen (CZ) Grenze. In der grenzüberschreitenden Region bestehend aus dem Isergebirge (CZ), dem Lausitzer Gebirge (CZ) und dem Zittauer Gebirge und Vorland (D) wurden im Rahmen des Projektes DiverGrass 12 Experimentalflächen auf verschiedenen Grasland-Typen eingerichtet. Auf denen werden verschiedene Maßnahmen zur Stabilisierung und Förderung eines guten Erhaltungszustandes der Grasländer erprobt, um den weiteren Verlust seltener Arten entgegenzuwirken und die Diversität der Standorte bestenfalls zu erhöhen.

\section{DIVERGRASS - PROJEKT TRANSGRANICZNY NA RZECZ ZRÓWNOWAŻONEGO ZARZĄDZANIA ZBIOROWISK TRAWIASTYCH}

Większość europejskich łąk i pastwisk to intensywnie użytkowane, półnaturalne i tymczasowe użytki zielone. Półnaturalne, w większości gatunkowo bogate, zbiorowiska trawiaste były na przestrzeni wieków utrzymywane poprzez rolniczą działalność człowieka. Jednak obecnie bardziej nowoczesnym i powszechnym zjawiskiem jest intensywne użytkowanie zbiorowisk trawiastych. Wypasanie bydła stanowi podstawowy sposób stosowany na pastwiskach, natomiast łąki są regularnie koszone. Połączenie tych dwóch sposobów jest typowe dla wypasanych łąk. Brak defoliacji zbiorowisk trawiastych, ekstensyfikacja lub nadmierna gospodarka intensywna może skutkować zmniejszeniem różnorodności gatunkowej roślin, a także wyplenieniem zagrożonych gatunków roślin. 
Zmniejszanie różnorodności gatunkowej zbiorowisk trawiastych na naturalnych stanowiskach stanowi jeden $\mathrm{z}$ kluczowych problemów w zakresie ochrony przyrody po obu stronach czesko-niemieckiej granicy. W ramach projektu DiverGrass, realizowanego na terenach transgranicznych obejmujących Góry Izerskie (CZ), Góry Łużyckie (CZ) oraz Góry Żytawskie wraz z ich przedgórzem (DE) założono 12 punktów eksperymentalnych w celu znalezienia optymalnych zabiegów mających na celu zatrzymanie zmniejszania lub zwiększenie różnorodności gatunkowej roślin na stanowiskach ze zbiorowiskami trawiastymi. 